\title{
78. $B_{x}$, Another Allele of the ABO Locus and its Heredity
}

\author{
By Hideo Yamaguchi, ${ }^{*)}$ Yasuto OKubo, ${ }^{*}$ Fumio \\ Hazama, ${ }^{*)}$ and Shizuo OYAMA**) \\ (Comm. by Tanemoto FuRuhatA, M.J.A., May 9, 1964)
}

Since June 1962, the authors have examined about 80,000 blood specimens and typed them at the request of the welfare authorities of the Prefectural Office of Osaka. Among the samples were 18 weak $\mathrm{B}$ and 6 weak $\mathrm{A}$ bloods, besides some $\mathrm{A}_{2}$ group bloods. We have in the literature several examples of the so-called $\mathrm{B}_{\mathrm{x}}$ or $\mathrm{B}_{\mathrm{m}}$ blood type, all from the Japanese people. ${ }^{1)-6)}$

However, the genetics of this blood type has not been determined. In this paper we present 3 families including 18 individuals either of $\mathrm{B}_{\mathrm{X}}$ or of $\mathrm{AB}_{\mathrm{X}}$ blood type that were discovered in the course of this work. All the families are natives of Osaka and its suburbs, Japan.

Serological Findings. To ordinary blood typing procedures the $B_{X}$ blood appears as of the group $O$ missing anti-B antibody, and $A B_{X}$ blood appears as of the group $A$ devoid of anti-B antibody. So, we made various attempts, such as treatment with enzymes (bromelin and ficin) and indirect Coombs' test to enhance the affinity of the cells to anti-B, using several high-titered sera. But the cells were not agglutinated.

As was to be expected, the $B_{x}$ and $A B_{x}$ cells absorbed much less anti-B than did normal $B$ red cells, but the eluates from the $B_{X}$ cells contained more antibody than did eluates prepared from the normal B blood. This paradoxical finding of greater activity of eluates prepared from the weak $B$ blood had been pointed out by Levine et al. ${ }^{7}$ This effect did not occur to the eluates from the $A_{\mathrm{x}}$ cells. Only one of the 39 O-group sera (anti-A+B) tested, agglutinated these cells on the slide test.

The $B_{x}$ cells showed nearly the same activity as normal $O$ cells with anti-H (eel and Ulex europaeus extract), though the $\mathrm{AB}_{\mathrm{x}}$ reacted at a slightly lower titre. Similar observation has been made by several investigators on the weak $\mathrm{B}$ and $\mathrm{A}$ cells. ${ }^{5)-8)}$

All the sera from the $B_{X}$ individuals contained normal anti-A antibody, but neither anti-B nor any atypical antibody was detected. The sera from the $\mathrm{AB}_{\mathbf{X}}$ group blood were devoid of antibody of any kind.

Tests for the B-substance in sera on some of the picked-up

*) The Osaka Red Cross Hospital, Osaka Red Cross Blood Bank.

**) Public Health Centre of Tondabayashi, Osaka. 
materials indicated that the $B_{x}$ and $A B_{x}$ sera contained this substance in a somewhat smaller quantity, compared with the normal B group serum.

The $B_{x}$ and $A B_{x}$ individuals secreted in saliva as much B-substance as did the normal $B$ individuals. The $\mathrm{H}$-substance level in saliva of the $B_{X}$ and $A B_{X}$ individuals was as high as in the normal O-group individuals. The saliva of the non-secretors of the $B_{X}$ individual (II-5 and III-1 of M. Family) contained a small amount of both Band $\mathrm{H}$-substance, indicating that the gene responsible for $\mathrm{B}_{\mathrm{X}}$ is independent of the secretor gene.

From the above findings, it seems safe to conclude that the $B_{x}$ (and $\mathrm{AB}_{\mathrm{x}}$ ) phenotypes reported here are to be classified serologically as a variant $B$ belonging to the 2nd category of weak B (Race and Sanger, 1962) ${ }^{9}$ in which no anti-B is present in serum but B- and $\mathrm{H}$-substance are found in saliva.

In case it is preferable to designate this weak B in analogy to weak $A$, it may be better to use $B_{m}$, provided that the suffix " $m$ " does not mean "modifying".

Pedigree Studies. 1) M. Family (Fig. 1): This is the largest of the 3 families and includes 13 individuals either of $B_{X}$ or of $A B_{X}$ type. In this family the $B_{x}$-gene was transmitted through 2 or 3 generations. There are two matings between $\mathrm{AB}_{\mathrm{x}}$ and $\mathrm{O}$ individuals (II- $1 \times$ II-2 and II- $6 \times$ II-7) in which the genotypes of the progeny may be reasonably inferred.

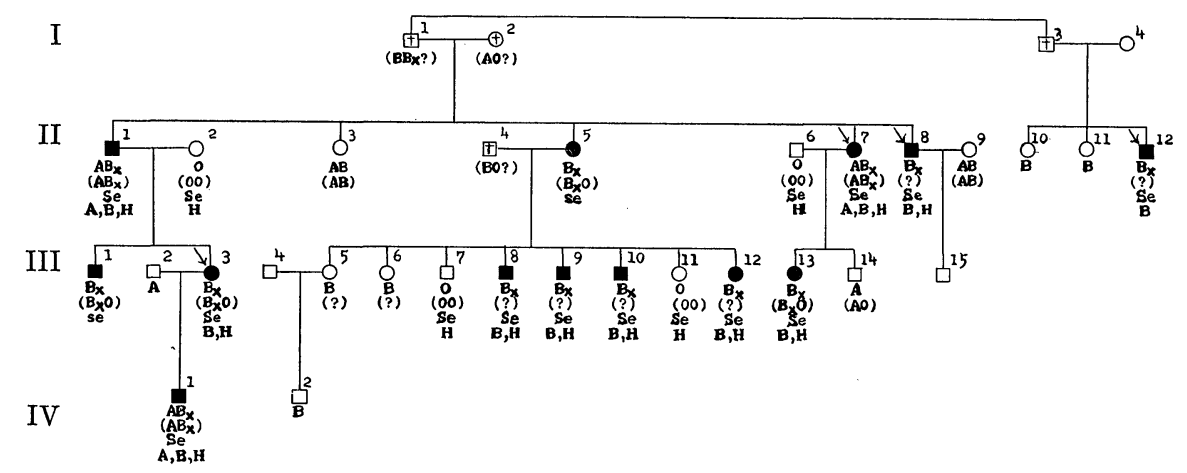

Fig. 1. M. Family. Probable genotypes are shown in brackets.

II-5 has 8 children of whom 4 (III-8, 9, 10 and 12) exhibit the $B_{x}$ phenotype, though their genotypes are unknown. It seems nearly certain that II-5 is $B_{x} O$, because she has two $O$ children. From the fact that II-1 is $A B_{x}, \mathrm{II}-3 A B$, II-5 $B_{x} O$, and II-7 $A B_{x}$ respectively, the genotypes of their parents (I-1 and I-2) may be assumed as $B B_{x}$ (I-1) and $A O(\mathrm{I}-2)$. A cousin of $\mathrm{II}-1-8, \mathrm{II}-12$, is also $\mathrm{B}_{\mathrm{x}}$. 
Two of the $\mathrm{B}_{\mathrm{x}}$ individuals (II-5 and III-1) were found to be nonsecretors.

The analysis of this family indicates that the $\mathrm{B}_{\mathrm{x}}$ blood type is due to an allele at the $\mathrm{B}$ locus and the genotypes $B_{x} O$ and $A B_{x}$ are manifested as of the $\mathrm{B}_{\mathrm{X}}$ and $\mathrm{AB}_{\mathrm{X}}$ type respectively. The phenotype of the genotype $B B_{x}$ remains to be shown.

2) I. Family (Fig. 2): The propositus, II-4 has 3 children of phenotypes $\mathrm{B}(\mathrm{III}-3), \mathrm{AB}_{\mathrm{X}}(\mathrm{III}-4)$, and $\mathrm{B}(\mathrm{III}-5)$. Her husband, II-3 is of the $\mathrm{AB}$ group, so, she had been suspected to belong to either $B_{x} O$ or $B B_{x}$. Her sister, II-2 who has the normal $\mathrm{B}$ blood, married to a $B$ group husband (II-1) and gave birth to 2 children (III-1,2) both of the $\mathrm{B}_{\mathrm{X}}$ phenotype. Since this $B_{x}$-gene should have been derived from the mother, she probably has the $B_{x}$-gene, even though she presented herself as a normal $B$ individual, with nothing abnormal in her saliva.

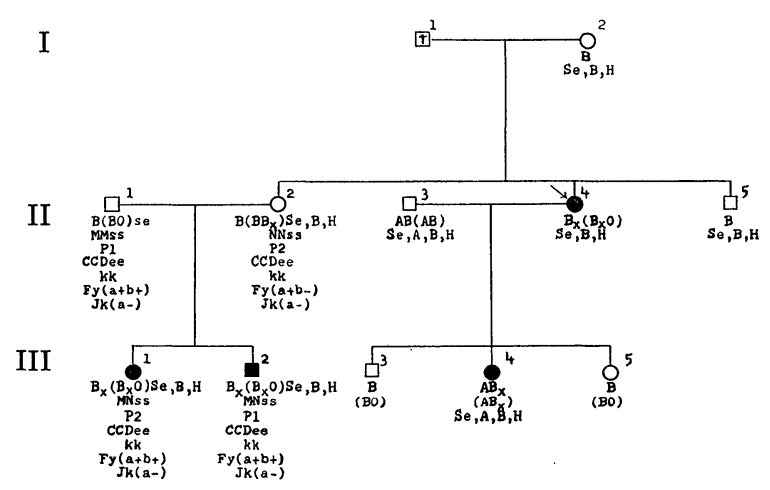

Fig. 2. I. Family.

Although this pedigree is less extensive than M., it is a valuable one, as every example showing interaction of the $B_{x}$-gene against $A$-, $B$ - or $O$-gene is represented, and it is demonstrated that the $B B_{x}$ genotype is manifested as $\mathrm{B}$ phenotype, $B_{x}$-gene behaving as a recessive to the $B$-gene.

3) K. Family (Fig. 3): This family includes only one $B_{X}$ member, (III-1). The course of transmission of this gene could not be followed in this pedigree, in spite of our effort using all available means to clarify this point. There was nothing striking other than that concerning the ABO system.

Four conjectures were made of the blood type of this individual, following some previous authors:- i) an allele of $\mathrm{ABO},{ }^{7)}$ ii) a recessive modifying gene of $\mathrm{B},{ }^{10)}$ iii) a new mutation, and iv) environmental effect on the manifestation of the normal $A B O$-genes, for instance, leukaemia. ${ }^{11)-13)}$ 


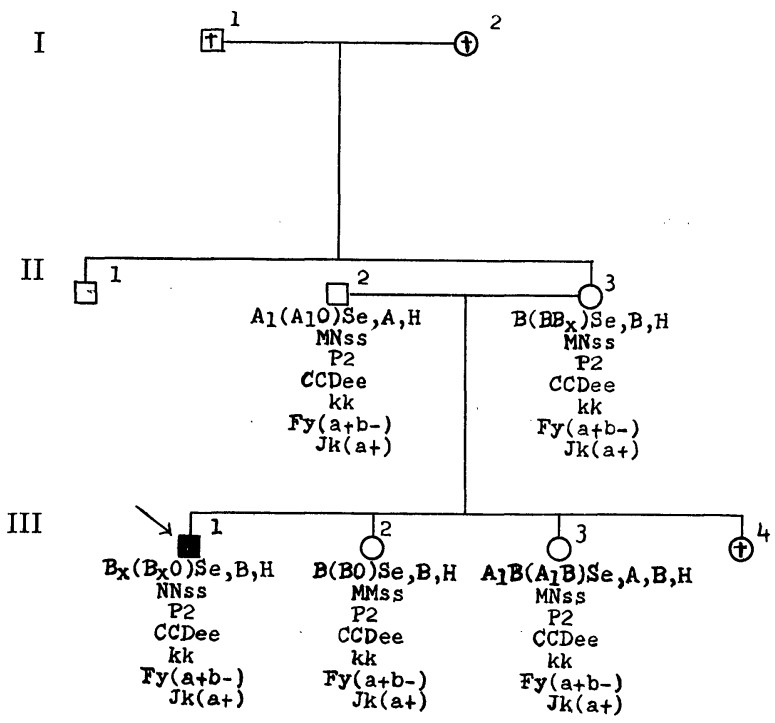

Fig. 3. K. Family.

The last possibility was ruled out because, although we had kept the propositus under observation for about 2 years, there were no changes in his blood nor in any other health condition.

If II-1, the propositus' uncle, whose blood sample has not been available, has the $B_{x}$-gene, the third possibility would be ruled out.

For the present, it seems more reasonable to assume the first possibility - the propositus has a rare allele of $\mathrm{ABO}$ system. The genotype of the propositus' mother, II-3 is probably $B B_{x}$, though she appeared to have normal $\mathrm{B}$ blood.

Throughout these 3 families, the serological findings of all the $\mathrm{B}_{\mathrm{X}}$ (and $\mathrm{AB}_{\mathrm{X}}$ ) individuals are nearly identical, if not exactly so. Accordingly, it seems to be warranted to conclude that the $B_{x}$ and $\mathrm{ABx}$ bloods reported here are due to another allele at the $\mathrm{ABO}$ locus.

Acknowledgements. The authors wish to offer their thanks to Dr. T. Furuhata, Dr. T. Komai for their kind discussion and revision of this report and also to Dr. R. Kimura for his constant encouragement.

\section{References}

1) Yokoyama, M., Stacey, S. M., and Dunsford, I.: Vox Sang., 2, 348 (1957).

2) Yokoyama, M., Barber, M., and Dunsford, I.: Juntendo Med. J., 5, 273 (1959).

3) Hashimoto, Y., Ukai, A., Kano, S., Shirai, T., Ono, S., and Yokoyama, M.: J. Jap. Soc. Blood Trans., 7, 160 (1960).

4) Murakami, S., Tokunaga, E., Nagao, M., and Asanuma, T.: J. Jap. Soc. Blood Trans., 8, 181 (1961).

5) Kitahama, M.: J. Jap. Soc. Blood Trans., 9, 38 (1962). 
6) Nakajima, H., Shikura, I., and Akabane, J.: J. Jap. Soc. Blood Trans., 9, 39 (1962).

7) Levine, P., Celano, M., and Griset, T.: Proc. 6th Cong. Int. Soc. Blood Trans., 132 (1958).

8) Weiner, W., Lewis, H. B. M., Moore, P., Sanger, R., and Race, R. R.: Vox Sang., 2, 25 (1957).

9) Race, R. R., and Sanger, R.: Blood Groups in Man. 4th ed. Blackwell Scientific Publications, Oxford (1962).

10) Kitahama, M., Yamaguchi, H., Okubo, Y., and Hazama, F.: to be published.

11) Renton, P. H., Stratton, F., Gunson, H. H., and Hancock, J. A.: Brit. Med. J., i, 294 (1962).

12) Bartova, A., Novotony, Z., and Slepicka, J.: Blood, 14, 566 (1962).

13) Hart, Mia van der, Veer, Marga van der, and Loghem, J. J. van: Vox Sang., 7, 449 (1962). 